\title{
Faktor-Faktor Yang Berhubungan Dengan Kepatuhan Pasien Diabetes Melitus Dan Hipertensi Dalam Mengikuti Kegiatan Prolanis
}

\author{
${ }^{1}$ Suriani,S. L. ${ }^{1}$ Momot, ${ }^{1}$ Yogik Setia Anggreni \\ ${ }^{1}$ Jurusan Keperawatan Poltekkes Kemenkes Sorong \\ Email : Yogiksetiaanggreni@gmail.com
}

\author{
Artikel history \\ Dikirim, Februari $4^{\text {th }}, 2019$ \\ Ditinjau, Februari $18^{\text {th }}, 2019$ \\ Diterima, Juni $13^{\text {th }}, 2019$
}

\begin{abstract}
ABSTRACK
Degenerative disease is currently a very important concern in the public health sector, because it has a predicate as a cause of high rates of morbidity and mortality. Therefore, the management of degenerative diseases such as diabetes mellitus and hypertension must be truly implemented. Prolanis activities launched by the government to help manage diabetes mellitus and hypertension have been promoted. However, there are still various problems such as lack of adherence to visits. Research Objectives: To determine the factors associated with adherence to patients with diabetes mellitus and hypertension in taking part in prolanist activities in the puskesmas in the city of Sorong. Research methodology: This type of research is quantitative research using a cross sectional approach. The number of samples is 25 respondents taken using accidental sampling technique. The measuring instrument used in this study is a questionnaire. Results: Chi square statistical test results of the relationship of access to services with compliance obtained 0.072>0.05. Long membership relationship with compliance obtained $0.024<0.05$. The relationship between the availability of facilities and facilities and compliance was $0.58<0.05$. Conclusion: Access to prolanis services has nothing to do with respondents' compliance in participating in prolanist activities. Long time being a member of Prolanis has a relationship with the compliance of respondents in participating in prolanis activities. The availability of facilities and facilities is not related to the compliance of respondents in participating in prolanist activities.
\end{abstract}

Keywords: Hypertension, diabetes mellitus, prolanis, access to services, length of membership, availability of facilities and facilities

\begin{abstract}
ABSTRAK
Penyakit degeneratif saat ini menjadi perhatian yang sangat penting pada sektor kesehatan masyarakat, karena memiliki predikat sebagai penyebab tingginya angka kesakitan dan kematian. Oleh sebab itu, penatalaksanaan penyakit degeneratif seperti diabetes melitus dan hipertensi harus benarbenar dilaksanaakan. Kegiatan Prolanis yang dicanangkan pemerintah untuk membantu penatalaksanaan diabetes melitus dan hipertensi telah digalakan. Namun, masih terdapat berbagai masalah seperti kurang patuh dalam kunjungan. Tujuan Penelitian : Untuk mengetahui factor-faktor yang berhubungan dengan kepatuhan pasien diabetes mellitus dan hipertensi dalam mengikuti kegiatan prolanis di puskesmas malanu kota sorong. Metodologi penelitian : Jenis penelitian ini adalah penelitian kuantitatif dengan menggunakan pendekatan cross sectional. Jumlah sampel adalah 25 responden yang diambil menggunakan teknik accidental sampling. Alat ukur yang digunakan dalam penelitian ini berupa kuesioner. Hasil : Hasil uji statistik chi square hubungan akses ke pelayanan dengan kepatuhan didapatkan 0.072>0.05. Hubungan lama keanggotaan dengan kepatuhan didapatkan 0.024<0.05. Hubungan ketersediaan sarana dan fasilitas dengan kepatuhan didapatkan $0.58<0.05$. Kesimpulan : Akses ke pelayanan prolanis tidak ada hubungan dengan kepatuhan responden dalam mengikuti kegiatan prolanis. Lama menjadi anggota Prolanis ada hubungan dengan kepatuhan responden dalam mengikuti kegiatan prolanis. Ketersediaan sarana dan fasilitas prolanis tidak ada hubungan dengan kepatuhan responden dalam mengikuti kegiatan prolanis.
\end{abstract}

Kata Kunci : Hipertensi, Diabetes Melitus, Prolanis, Akses Pelayanan, Lama Keanggotaan, Ketersediaan Sarana Dan Fasilitas. 


\section{PENDAHULUAN}

Penyakit tidak menular saat ini menjadi perhatian yang sangat penting pada sektor kesehatan masyarakat, karena memiliki predikat sebagai penyebab tingginya angka kesakitan dan kematian. Berdasarkan Global Status Report on Non-communicable Disease sebanyak 63\% kematian di dunia disebabkan oleh penyakit tidak menular, seperti penyakit kardiovaskuler, diabetes, kanker, dan penyakit pernafasan, dan $80 \%$-nya terjadi di negara berpendapatan menengah ke bawah (lower-middle income) (WHO, 2015).

WHO memperkirakan, secara global, kasus kematian akibat penyakit tidak menular akan meningkat sebanyak 52 juta jiwa dalam kurun waktu 1 dekade (2010 - 2020). Peningkatan kasus kematian tertinggi berada di wilayah Afrika, Asia Tenggara, dan Mediterania Timur dengan persentase lebih dari $20 \%$. Penyakit tidak menular yang menjadi penyebab kematian utama di dunia adalah penyakit kardiovaskuler (17 juta kematian atau $48 \%$ dari kematian akibat penyakit tidak menular), kanker (7,6 juta kematian atau $21 \%$ dari kematian akibat penyakit tidak menular), penyakit pernafasan, termasuk asma dan PPOK (4,2 juta kematian), dan diabetes (1,3 juta kematian). Lebih dari $80 \%$ kematian akibat penyakit kardiovaskuler dan diabetes terjadi di negara berpendapatan menengah ke bawah (WHO, 2015).

Diabetes Melitus (DM) adalah suatu sindroma gangguan metabolisme yang ditandai dengan hiperglikemia yang berhubungan dengan abnormalitas metabolisme karbohidrat, lemak dan protein, disebabkan oleh defisiensi insulin relatif atau absolut (Inzuchi, 2003). Gambaran patologik diabetes melitus sebagian besar dapat dihubungkan dengan salah satu efek utama akibat kurangnya insulin yaitu berkurangnya pemakaian glukosa oleh sel-sel tubuh. Peningkatan metabolisme lemak yang menyebabkan terjadinya metabolisme lemak abnormal disertai endapan kolesterol pada dinding pembuluh darah sehingga timbul gejala aterosklerosis serta berkurangnya protein dalam jaringan tubuh (Guyton, 2006).

Menurut laporan badan kesehatan dunia (WHO), pada tahun 2016 sebanyak 18.060.000 juta jiwa di Indonesia menderita diabetes melitus. Diperkirakan akan meningkat menjadi 12 juta jiwa pada tahun 2020. Berdasarkan data ini dapat terlihat bahwa akan terjadi peningkatan 2 sampai 3 kali lipat penderita diabetes melitus di Indonesia pada tahun 2030. Indonesia sendiri menduduki peringkat ke lima setelah Bangladesh, Bhutan, Korea Selatan dan India (WHO, 2016). Prevalensi penyakit diabetes di Papua Barat sebesar 0,8\%, tertinggi di Kabupaten Nabire sebesar 1,8\%. Prevalensi penyakit tumor/ kanker sebesar 0,3\%, tertinggi di Kabupaten Merauke, Asmat, dan Sarmi masingmasing 1,1\% (Profil Kesehatan Papua, 2014).

Selain diabetes mellitus, penyakit menular dan generatif yang masih menjadi masalah kesehatan serius di seluruh dunia adalah hipertensi. Penyebabnya antara lain prevalensi hipertensi yang semakin meningkat, sedikitnya penderita yang mendapatkan terapi adekuat, masih banyaknya penderita yang tidak terdeteksi, serta tingginya morbiditas 
dan mortalitas akibat komplikasi hipertensi (Suiraoka, 2012). Organisasi Kesehatan Dunia tahun 2013 menyebutkan bahwa hampir 9.4 juta jiwa diseluruh dunia menderita hipertensi dan masalah ini terus meningkat. Asia tenggara merupakan region yang memiliki penderita hipertensi tertinggi ke-5 di dunia (WHO, 2013).

Indonesia merupakan negara tertinggi ke-2 di Asia Tenggara setelah Myanmar yang memiliki prevalensi hipertensi yang cenderung meningkat. Persentase penderita hipertensi di Indonesia meningkat dari 8\% pada tahun 1995 menjadi 32\% di tahun 2008. Peningkatan presentase ini terjadi pada pria dengan $42.7 \%$ dibandingkan wanita yang hanya 39.2\% (WHO, 2013). Angka kejadian hipertensi di Papua Barat juga cenderung meningkat dari tahun ke tahun. Berdasarkan laporan rumah sakit dan Puskesmas di Papua Barat, prevalensi kasus hipertensi pada tahun 2013 yaitu sebanyak 179.874 kasus (InFoDatin, 2013).

Diabetes melitus tipe 2 dan hipertensi merupakan faktor risiko lesi aterosklerosis yang berhubungan dengan dislipidemia (Nguyen, T, 2012). Pasien diabetes melitus tipe 2 mempunyai beberapa abnormalitas lipid, meliputi peningkatan trigliserida plasma (karena peningkatan very low density lipoprotein dan lipoprotein remnant), peningkatan kadar low density lipoprotein dan penurunan kadar high density lipoprotein kolesterol (Muliyati Hepti, 2011).

Menurut Umiyati (2011), hipertensi dan abnormalitas lipid sering terjadi bersamaan. Masingmasing merupakan faktor risiko terjadinya penyakit kardiovaskuler. Disamping itu, kemungkinan timbulnya gangguan koroner semakin besar ketika dua masalah tersebut terjadi bersamaan. Hipertensi berhubungan dengan gangguan lipid darah melalui banyak cara dan memberi kontribusi pada keseluruhan resiko terjadinya penyakit kardiovaskuler (Hamano, 2012).

Dislipidemia, hipertensi, dan diabetes melitus telah disorot sebagai prediktor awal penyakit kardiovaskuler (Mozaffarian et al., 2008). Hipertensi adalah penyakit yang umum menyertai pada pasien diabetes dan pada hakekatnya meningkatkan risiko terjadinya penyakit kardiovaskuler pada populasi pasien ini. Salah satu faktor yang berpengaruh terhadap terjadinya hipertensi adalah meningkatnya kadar LDL kolesterol pada penderita diabetes melitus tipe 2 (Aurelio Leone, 2011). Studi Framingham melaporkan bahwa LDL kolesterol merupakan suatu komponen yang aterogenik mempunyai dampak klinis pada penyakit kardiovaskuler (Ansari et al, 2012).

Melihat banyaknya kasus hipertensi dan diabetes melitus di Indonesia yang semakin meningkat setiap tahunnya, didukung LDL yang merupakan salah satu faktor terjadinya hipertensi pada diabetes melitus, maka peneliti ingin meneliti perbedaan kadar LDL pada pasien diabetes melitus tipe 2 dengan hipertensi dan tanpa hipertensi. Komplikasi diabetes yang dapat terjadi yaitu kebutaan. Kebutaan pada penderita diabetes melitus di Indonesia diperkirakan $6,4 \%$ dari $64 \%$ penderita yang mengalami komplikasi (Sitompul, 2011). Upaya 
pencegahan merupakan cara terbaik dalam menghindari komplikasi diabetes melitus. Pencegahan komplikasi yang dapat dilakukan berupa pemeriksaan dan pengobatan tekanan darah, perawatan kaki diabetes, pemeriksaan mata secara rutin pemeriksaan protein dalam urine, menghentikan kebiasaan merokok. Penyakit ini tidak dapat disembuhkan, tetapi bisa dikelola dengan mematuhi empat pilar penatalaksanaan diabetes melitus meliputi pendidikan kesehatan, perencanaan makan/diet, latihan fisik teratur dan minum obat hipoglikemik oral $(\mathrm{OHO})$ atau insulin seumur hidup (Soegondo, 2005).

Sacket dalam Niven (2005), menyatakan untuk mendapatkan status kesehatan lebih baik, penderita diabetes melitus dianjurkan untuk patuh dalam melaksanakan penatalaksanaan diabetes melitus. Faktor yang mempengaruhi kepatuhan pada penderita diabetes mellitus antara lain kepercayaan diri, pengetahuan tentang penyakit, dukungan keluarga dan pendidikan nutrisi. Prinsip untuk meningkatkan kepatuhan meliputi dukungan yang positif untuk menghindari kecemasan, pemberian informasi secara bertahap, mulai dengan hal sederhana, penggunaan alat bantu pandang (audio visual), lakukan pendekatan dan stimulasi, materi penyuluhan meliputi pengaturan diet yang ditekankan pada $3 \mathrm{~J}$ : jenis, jadwal dan jumlah diet yang diberikan kepada pasien diabetes melitus dan hipertensi. Disamping itu materi penyuluhan difocuskan pada aktifitas fisik secara teratur dan penggunaan obat anti diabetik secara realistis. Ketiga hal ini merupakan kunci pokok keberhasilan program terapi diabetes melitus dan hipertensi (Budiyani, 2011).

Penyakit hipertensi tersebut dapat di atasi dengan cara mengurangi rokok, minuman yang berakohol, makanan yang mengandung banyak garam, olahraga yang teratur, jangan melakukan aktifitas fisik dan otak yang berlebihan, menghindari stress, depresi serta harus dapat mengontrol emosi, menerapkan pola dan gaya hidup yang teratur dan selaras dengan ajaran agama, serta rutin berkonsultasi dengan dokter (Pinzon, 2009). Salah satu program pemerintah yang mendorong penderita penyakit kronis termasuk pasien diabetes melitus dan hipetensi untuk mencapai kualitas hidup yang optimal adalah dengan diselanggarakannya Prolanis (Program Pengelolaan Penyakit Kronis). Dengan adanya aktifitas konsultasi medis/edukasi, home visit, reminder, aktifitas klub dan pemantauan kesehatan diharapkan para penyandang penyakit kronis dapat mencegah terjadinya komplikasi penyakit. Hal tersebut juga diterapkan di Puskesmas Malanu Kota Sorong yang telah menyelenggarakan kegiatan Prolanis yang di khususkan untuk penyakit diabetes mellitus dan hipertensi.

Berdasarkan studi pendahuluan yang dilakukan, didapatkan data bahwa anggota Prolanis yang menderita diabetes melitus dan hipertensi sebanyak 42 pasien. Namun kunjungan anggota mengalami penurunan yaitu rata-rata enam bulan terakhir ini adalah 27 anggota dengan berbagai alasan. Padahal kegiatan di Prolanis cukup 
beragam seperti penyuluhan, mengetahui factor-faktor yang pemeriksaan gulah darah, berhubungan dengan kepatuhan penimbangan berat badan dan pasien diabetes melitus dan hipertensi pengukuran tinggi badan.

Berdasarkan latar belakang tersebut, penulis tertarik untuk dalam mengikuti kegiatan Prolanis di puskesmas malanu.

\section{METODE}

Jenis penelitian ini adalah penelitian kuantitatif dengan menggunakan pendekatan cross sectional, yaitu rancangan penelitian dengan melakukan pengukuran atau pengamatan pada saat bersamaan atau sekali waktu (Hidayat, 2007; Nursalam, 2003). Penelitian ini dilaksanakan di Puskesmas Malanu

\section{HASIL}

Kota Sorong pada tanggal 16 Agustus 2017. Populasi dalam penelitian ini adalah seluruh anggota Prolanis di Puskesmas Malanu Kota Sorong yang berjumlah 42 orang. Sampel dalam penelitian ini berjumlah 25 anggota Prolanis di Puskesmas Malanu Kota Sorong.

1. Karakteristik responden

Distribusi responden menurut umur, jenis kelamin, tingkat pendidikan, jenis pekerjaan dapat dilihat pada tabel 4.1 berikut ini :

Tabel 1. Distribusi karakteristik responden

\begin{tabular}{lcc}
\hline Karakteristik & F & \% \\
\hline Penyakit yang diderita & 5 & 20 \\
Diabetes melitus & 12 & 48 \\
Hipertensi & 8 & 32 \\
DM \& Hipertensi & $\mathbf{2 5}$ & $\mathbf{1 0 0}$ \\
\hline Total & & \\
\hline Umur & 16 & 64 \\
$45-59$ tahun & 8 & 32 \\
$60-74$ tahun & 1 & 40 \\
$75-90$ tahun & $\mathbf{2 5}$ & $\mathbf{1 0 0}$ \\
\hline Total & & 32 \\
\hline Jenis kelamin & 8 & 68 \\
\hline Laki-Laki & 17 & $\mathbf{1 0 0}$ \\
Perempuan & $\mathbf{2 5}$ & \\
\hline Total & & 56 \\
Bingkat pendidikan & 14 & 28 \\
Q Rendah & 7 & 16 \\
r Menengah & 4 & $\mathbf{1 0 0}$ \\
Qerguruan tinggi & $\mathbf{2 5}$ & 92 \\
\hline Total & 23 & $\mathbf{1 0 0}$ \\
\hline Senis pekerjaan & 2 & \\
aTidak kerja & $\mathbf{2 5}$ & \\
rBekerja & & \\
K Total & & \\
\hline
\end{tabular}


Berdasarkan tabel 1 didapatkan bahwa sebagian besar responden yang terlibat dalam penelitian ini menderita Hipertensi sebanyak $12 \quad(48 \%)$ responden yang berusia $45-$ 59 tahun sebanyak $16(64 \%)$

responden, berjenis kelamin perempuan sebanyak 17 (68\%) responden. Responden ini berpendidikan rendah 14 (56\%) dan tidak bekerja 23 $(92 \%)$

\section{Analisa Univariat}

Tabel 2. Distribusi lama keanggotaan Prolanis dan tingkat kepatuhan serta pandangan terhadap ketersediaan fasilitas Prolanis, akses ke Prolanis di Prolanis Puskesmas Malanu Kota Sorong

\begin{tabular}{|c|c|c|}
\hline Variabel & f & $\%$ \\
\hline \multicolumn{3}{|c|}{ Ketersediaan fasilitas Prolanis } \\
\hline Kurang & 3 & 12 \\
\hline Cukup & 12 & 48 \\
\hline Baik & 10 & 40 \\
\hline Total & 25 & 100 \\
\hline \multicolumn{3}{|l|}{ Akses ke Prolanis } \\
\hline$<2 \mathrm{KM}$ & 13 & 52 \\
\hline$\geq 2 \mathrm{KM}$ & 12 & 48 \\
\hline Total & 25 & 100 \\
\hline \multicolumn{3}{|l|}{ Lama keanggotaan Prolanis } \\
\hline$<1$ tahun & 3 & 12 \\
\hline$\geq 1$ tahun & 22 & 88 \\
\hline Total & 25 & 100 \\
\hline \multicolumn{3}{|l|}{ Tingkat kepatuhan } \\
\hline Tidak patuh (hadir $<3$ kali) & 10 & 40 \\
\hline Patuh (hadir >_3 kali) & 15 & 60 \\
\hline Total & 25 & 100 \\
\hline
\end{tabular}

Sumber, Data Primer 2017

Berdasarkan tabel 2 didapatkan bahwa $12(48 \%)$ responden berpandangan bahwa fasilitas Prolanis cukup untuk dilaksanakannya kegiatan Prolanis. Akses responden ke pelayanan prolanis sebagian besar $<2 \mathrm{Km}$ yaitu sebanyak 13

2. Analisa bivariat

a. Hubungan akses ke pelayanan Prolanis terhadap kepatuhan pasien diabetes
(52\%) responden. Sebagian besar responden sudah menjadi anggota Prolanis $\geq 1$ tahun yaitu $22(88 \%)$ responden dengan tingkat kepatuhan $15 \quad(60 \%)$ dalam 3 bulan terakhir.

melitus dan hipertensi dalam mengikuti kegiatan Prolanis di Puskesmas Malanu Kota Sorong 
Tabel 3. Tabel silang hubungan akses ke fasilitas pelayanan Prolanis terhadap kepatuhan pasien diabetes melitus dan hipertensi dalam mengikuti kegiatan Prolanis di Puskesmas Malanu Kota Sorong Tahun 2017

\begin{tabular}{lcccccc}
\hline \multirow{2}{*}{ Akses Ke Prolanis } & \multicolumn{4}{c}{ Kepatuhan } & \multirow{2}{*}{ Total } \\
\cline { 2 - 6 } & \multicolumn{2}{c}{ Tidak patuh } & \multicolumn{3}{c}{ Patuh } & \\
\cline { 2 - 6 } & $\mathrm{f}$ & $\%$ & $\mathrm{f}$ & $\%$ & $\mathrm{f}$ & $\%$ \\
\hline$<2 \mathrm{KM}$ & 3 & 23.1 & 10 & 76.9 & 13 & 100 \\
$\geq 2 \mathrm{KM}$ & 7 & 58.3 & 5 & 41.7 & 12 & 100 \\
\hline Total & 10 & 40 & 15 & 60 & 25 & 100 \\
\hline$\alpha: 0.05$ & & & \multicolumn{4}{c}{$X^{2}:$} \\
\hline
\end{tabular}

Sumber : Hasil tabulasi silang, 2017

Berdasarkan tabel 4.3 dapat di jelaskan bahwa akses ke Prolanis $<2 \mathrm{~km}$ terhadap kepatuhan yang tidak patuh lebih sedikit (23.1) daripada yang patuh (76.9) sedangkan akses ke pelayanan prolanis $\geq 2 \mathrm{~km}$ terhadap kepatuhan yang tidak patuh lebih besar (58.3) daripada yang patuh (41.7). Hasil penelitian dengan

b. Hubungan lama keanggotaan terhadap kepatuhan pasien diabetes melitus dan hipertensi menggunakan uji statistik chi square didapatkan $p$ Value $=$ $(0.072)>(a=0.05)$ maka $\mathrm{H}_{\mathrm{O}} \mathrm{di}$ terima atau tidak ada hubungan anatara akses ke pelayanan prolanis dengan kepatuhan pasien diabetes militus dan hipertensi dalam mengikuti kegiatan Prolanis di puskesmas malanu Kota Sorong.

dalam mengikuti kegiatan Prolanis

Tabel 4 Tabel silang hubungan lama keanggotaan terhadap kepatuhan pasien diabetes melitus dan hipertensi dalam mengikuti kegiatan Prolanis di Puskesmas Malanu Kota Sorong tahun 2017

\begin{tabular}{lcccccc}
\hline \multirow{2}{*}{ Lama Keanggotaan } & \multicolumn{4}{c}{ Kepatuhan } & \multirow{2}{*}{ Total } \\
\cline { 2 - 6 } & \multicolumn{2}{c}{ Tidak patuh } & \multicolumn{2}{c}{ Patuh } & \multicolumn{2}{c}{} \\
\cline { 2 - 7 } & $\mathrm{F}$ & $\%$ & $\mathrm{f}$ & $\%$ & $\mathrm{f}$ & $\%$ \\
\hline$<1$ tahun & 3 & 100 & 0 & 0 & 3 & 100 \\
$\geq 1$ tahun & 7 & 31.8 & 15 & 68.2 & 22 & 100 \\
\hline Total & 10 & 40 & 15 & 60 & 25 & 100 \\
\hline$\alpha: 0.05$ & & & & & $X^{2}: 0.024$ \\
\hline
\end{tabular}

Sumber : Data Primer, 2017 
Berdasarkan tabel 4 dapat di jelaskan bahwa lama keangotaan $<1$ tahun terhadap kepatuhan yang tidak patuh lebih besar $(100 \%)$ daripada yang patuh $(0 \%)$. Sedangkan lama keanggotaan $\geq 1$ tahun terhadap kepatuhan yang tidak patuh lebih sedikit (31.8\%) daripada yang patuh $(68,2 \%)$. Hasil penelitian dengan

c.Hubungan ketersediaan sarana dan fasilitas terhadap kepatuhan pasien diabetes melitus dan menggunakan uji statistik chi square didapatkan $p$ Value $=$ $(0.024)<(a=0.05)$ maka $\mathrm{H}_{\mathrm{O}} \mathrm{di}$ tolak atau ada hubungan antara lama keanggotaan prolanis dengan kepatuhan pasien diabetes militus dan hipertensi dalam mengikuti kegiatan Prolanis di puskesmas malanu Kota Sorong.

hipertensi dalam mengikuti kegiatan Prolanis

Tabel 5. Tabel silang hubungan ketersediaan sarana dan fasilitas terhadap kepatuhan pasien diabetes melitus dan hipertensi dalam mengikuti kegiatan Prolanis di Puskesmas Malanu Kota Sorong tahun 2017

\begin{tabular}{lcccccc}
\hline \multirow{2}{*}{$\begin{array}{c}\text { Ketersediaan } \\
\text { Sarana dan } \\
\text { Fasilitas }\end{array}$} & \multicolumn{4}{c}{ Kepatuhan } & \multirow{2}{*}{ Total } \\
\cline { 2 - 6 } & \multicolumn{2}{c}{ Tidak patuh } & \multicolumn{2}{c}{ Patuh } & \\
\cline { 2 - 7 } & $\mathrm{F}$ & $\%$ & $\mathrm{~F}$ & $\%$ & $\mathrm{~F}$ & $\%$ \\
\hline Kurang & 3 & 100 & 0 & 0 & 3 & 100 \\
Cukup & 5 & 41.7 & 7 & 58.3 & 12 & 100 \\
Baik & 2 & 20 & 8 & 80 & 10 & 100 \\
\hline Total & 10 & 40.0 & 15 & 60.0 & 25 & 100 \\
\hline$\alpha: 0.05$ & & & \multicolumn{4}{c}{$X^{2}: 0.058$} \\
\hline
\end{tabular}

Sumber : Data Primer, 2017

Berdasarkan Tabel 5 dapat dijelaskan bahwa ketersediaan sarana dan fasilitas kurang terhadap kepatuhan tidak patuh lebih besar $(100 \%)$ dari pada yang patuh $(0 \%)$. Ketersediaan saran dan fasilitas cukup terhadap kepatuhan yang tidak patuh lebih sedikit (41.7\%) dari pada yang patuh $(58.3 \%)$. Ketersedian sarana dan fasilitas baik terhadap kepatuhan yang tidak patuh lebih sedikit (20\%) dari pada yang patuh (80\%). Hasil penelitian dengan menggunakan uji statistik fisher didapatkan $p$ value $=$ $(0.058)>\quad(a=0.05)$ artinya ketersediaan sarana dan fasilitas Prolanis tidak ada hubungan dengan kepatuhan pasien diabetes mellitus dalam mengikuti kegiatan Prolanis di puskesmas malanu Kota Sorong 


\section{b. Pembahasan}

1. Hubungan akses ke pelayanan terhadap kepatuhan pasien diabetes mellitus dan hipertensi dalam mengikuti kegiatan prolanis di Puskesmas Malanu Kota Sorong

Hasil penelitian yang dilakukan bahwa tidak ada hubungan antara akses kepelayanan dengan kepatuhan responden dalam mengikuti kegiatan Prolanis, yang ditunjukkan dengan hasil uji statistik chy square X2 0.072 (p value > 0.05). Aksebilitas dalam penelitian ini diukur dari jarak tempuh responden ke fasilitas pelayanan yang terbagi menjadi $>2 \mathrm{~km}$ dan $<2 \mathrm{~km}$. Hasil penelitian ini berbeda dengan penelitian (Darmono. 2009) yang menemukan bahwa terdapat pengaruh aksesibilitas terhadap pemanfaatan puskesmas ditinjau dari frekuensi pengguna jasa pada puskesmas kecamatan di wilayah Jakarta Pusat. Penelitian Adri (2008) juga menemukan bahwa ada pengaruh antara faktor geografis (jarak, waktu tempuh, dan sarana transportasi) terhadap antenatal care.

Akses kepelayanan

Prolanis dapat mencakup jarak. Jarak membutuhkan waktu tempuh dan biaya. Tempat pelayanan yang lokasinya tidak strategis/sulit dicapai oleh para pasien menyebabkan berkurangnya akses pasien diabetes melitus dan hipertensi terhadap pelayanan Prolanis.

Walaupun ketersediaan pelayanan kesehatan sudah memadai, namun penggunaannya tergantung dari aksesibilitas masyarakat terhadap informasi (Barnes, Darryl E. 2004). Di Kelurahan Malanu, akses ke pelayanan kesehatan yang menyediakan pelayanan Prolanis telah tersedia. Namun, akses terlalu jauh dari pemukiman. Biasanya semakin jauh jarak/letak fasilitas kesehatan akan semakin enggan mereka datang.

Teori Andersen dan Newman (2005) menyatakan bahwa aksesibilitas merupakan komponen pendukung yang menyebabkan masyarakat menggunakan pelayanan kesehatan. Tidak adanya pengaruh yang bermakna antara aksesibilitas dengan kepatuhan kunjungan ke Prolanis dalam penelitian ini menunjukkan bahwa hal tersebut terkait dengan waktu tempuh dan beratnya medan tempuh/lokasi geografis. Hal ini sejalan dengan penelitian Naingolan et al (2016) bahwa ada hubungan yang bermakna antara waktu tempuh ke fasilitas kesehatan upaya kesehatan berbasis masyarakat (UKBM), waktu tempuh ke fasilitas kesehatan non UKBM dengan kelengkapan imunisasi anak bawah dua tahun (baduta) setelah dikontrol oleh variabel umur ibu, pendidikan ibu, pekerjaan ibu, status sosial ekonomi keluarga, dan wilayah tempat tinggal.

Hal ini sesuai dengan pendapat Andersen (2005) yang menjelaskan bahwa salah satu faktor yang mempengaruhi perilaku pemanfaatan pelayanan kesehatan adalah kebutuhan yang dirasakan (Perceived Need). Seseorang yang merasa sakit akan memanfaatkan pelayanan kesehatan dan 
sebaliknya, seseorang yang sebenarnya membutuhkan pelayanan kesehatan tetapi merasa sehat tidak akan memanfaatkan pelayanan kesehatan.

2. Hubungan lama keanggotaan terhadap kepatuhan pasien diabetes mellitus dan hipertensi dalan mengikuti kegiatan prolanis di puskesmas malanu Hasil uji statistik didapatkan lama menjadi anggota Prolanis berhubungan dengan kepatuhan responden dalam mengikuti kegiatan Prolanis dengan hasil chy square X2 0.024. Hasil penelitian ini berbeda dengan penelitian Maretha (2011) bahwa tidak terdapat hubungan secara statistik antara lamanya menjadi anggota kader dengan tanggapan kader terhadapt kunjungan masyarakat di Posyandu Puskesmas Jatimulya Kecamatan Tambun Selatan Kabupaten Bekasi tahun 2011. Hal ini disebabkan kader tetap memberikan kemampuannya kepada masyarakat karena telah menjadi tugas dan tanggung jawab.

\begin{tabular}{lr}
\multicolumn{1}{c}{ Lama } & keanggotaan \\
diekspresikan & sebagai \\
pengalaman yang & menunjukan \\
hubungan yang positif dengan & ral \\
kepatuhan. Hal & tersebut \\
mengindikasikan & bahwa
\end{tabular}
semakin lama keanggotaan seseorang, semakin menunjukan pemahamannya ia akan aktifitasnya. Lama menjadi anggota Prolanis menyebabkan pasien menjadi terbiasa dengan situasi di dalam anggota. Hal ini terbangun atas kualitas interaksi yang terbangun sejak lama. Kualitas interaksi antara anggota Prolanis atau dengan anggota professional kesehatan merupakan bagian yang penting dalam menentukan derajat kepatuhan (Robins, 2003).

Riset tentang faktorfaktor interpersonal yang mempengaruhi kepatuhan terhadap program terapi menunjukkan pentingnya sensitifitas tenaga kesehatan professional terhadap komunikasi verbal dan non verbal pasien, dan empati terhadap perasaan klien, akan menghasilkan suatu kepatuhan sehingga akan menghasilkan suatu kepuasan. Sunaryo (2006) mendefinisikan interaksi sosial adalah suatu hubungan antara dua atau lebih individu manusia dimana kelakuan individu yang satu mempengaruhi, mengubah atau memperbaiki kelakuan individu yang lain.

Ada dua syarat agar terjadi interaksi sosial yaitu adanya kontak sosial dan komunikasi. Kontak sosial merupakan aksi individu atau kelompok dalam bentuk isyarat yang memiliki makna bagi si pelaku dan si penerima membalas aksi tersebut dengan reaksi. Komunikasi hampir sama dengan kontak, tetapi adanya kontak belum tentu ada komunikasi. Kontak tanpa ada komunikasi tidak ada artinya. Soekanto (2001).

Program-program

pengobatan dapat dibuat sesederhana

mungkin dan pasien terlibat aktif dalam pembuatan program tersebut. Semakin lama seorang pasien menjadi anggota Prolanis, akan menentukan adaptasi terhadap keadaan dan kegiatan yang berlangsung. 
Niven (2002) mengungkapkan bahwa derajat kepatuhan bervariasi sesuai apakah program tersebut kuratif atau preventif, jangka panjang atau jangka pendek. Kepatuhan pasien terhadap program terapi yang bersifat kuratif dan dalam jangka waktu pendek memiliki presentase kepatuhan yang lebih tinggi dibandingkan dengan kepatuhan terhadap program terapi yang bersifat preventif dan memiliki jangka waktu yang lama.

3. Hubungan ketersediaan sarana dan fasilitas terhadap kepatuhan pasien diabetes mellitus dalam mengikuti kegiatan prolanis di puskesmas malanu

Hasil uji statistik didapatkan ketersediaan sarana dan fasilitas Prolanis tidak ada hubungan dengan kepatuhan responden dalam mengikuti kegiatan Prolanis hasil uji fisher X2 0.058. Hasil penelitian ini berbeda dengan penelitian Wulansari (2012) bawa terdapat hubungan antara kualitas pelayanan termasuk fasilitas (tangibles) dengan kepuasan ibu hamil terhadap pelayanan $\mathrm{di}$ BPRB Fitri Griya Husada Sewon Bantul. Menurut Notoatmodjo (2003) perilaku dapat disebabkan oleh banyak faktor. Faktor - faktor yang mempengaruhi perilaku antara lain pendidikan, pengetahuan, sikap dan fasilitas. Penelitian ini justru ketersediaan fasilitas kesehatan berpengaruh pada kepatuhan pasien hipertensi dan diabetes melitus untuk patuh mengikuti prolanis.

Fasilitas kesehatan merupakan prasarana dalam pelayanan kesehatan. Fasilitas yang baik akan mempengaruhi minat pasien untuk datang mengikuti kegiatan Prolanis dan secara langsung akan mempengaruhi taraf kesehatan yang lebih baik (Sukamto, 2007). Fasilitas atau sarana diperlukan untuk mendukung terjadinya perilaku patuh.

Puskesmas

Malanu memiliki ruang Prolanis sebagai fasilitas untuk berkumpul setiap bulannya. Tampak sangat nyaman untuk digunakan sebagai tempat berkumpul. Dimensi kenyamanan dalam mutu pelayanan tidak berhubungan langsung dengan efektivitas layanan kesehatan, tetapi mempengaruhi kepuasan pasien sehingga mendorong pasien untuk datang berobat kembali (Pohan,2006).

$$
\text { Menurut Satrinegara }
$$

(2014), dimensi dari kualitas pelayanan kesehatan yang telah banyak digunakan untuk mengukur mutu pelayanan kesehatan salah satunya adalah bukti nyata/dapat di raba (Tangibels). Wujud kenyataan secara fisik yang meliputi penampilan dan kelengkapan fasilitas fisik seperti ruang perawatan, gedung, tersedianya tempat parkir kebersihan, kerapian, dan kenyamanan ruangan tunggu dan ruang pemeriksaan, kelengkapan peralatan komunikasi dan penampilan.

Jika pasien hipertensi dan diabetes melitus memasuki fasilitas Prolanis dengan serangkaian harapan dan keinginan dan pada kenyataannya pengalamannya selama mendapatkan pelayanan di fasilitas kesehatan lebih baik seperti apa yang diharapkannya 
maka dia akan patuh. Di dalam situasi fasilitas kesehatan Prolanis, harus mengutamakan pihak yang dilayani (client oriented) karena pasien adalah klien yang terbanyak. Oleh sebab itu, banyak sekali manfaat yang dapat di peroleh bila mengutamakan kepuasan pasien.

\section{KESIMPULAN}

1. Tidak terdapat hubungan antara akses ke pelayanan prolanis dengan kepatuhan dalam mengikuti kegiatan Prolanis di Puskesmas Malanu Kota Sorong.

2. Tidak terdapat hubungan antara ketersediaan sarana dan fasilitas dengan kepatuhan pasien dalam mengikuti kegiatan Prolanis di Puskesmas Malanu Kota Sorong.

3. Terdapat hubungan antara lama keanggotaan dengan kepatuhan pasien dalam mengikuti kegiatan Prolanis di Puskesmas Malanu Kota Sorong.

\section{SARAN}

Bagi peneliti selanjutnya perlu dilakukan penelitian lebih mendalam menggunakan lembar observasi dan wawancara mendalam selain kuesioner dengan menggunakan variabel lain sehingga lebih mendapatkan data yang lengkap. Peneliti lain juga diharapkan melakukan penelitian jangka panjang dengan sampel yang ideal.

\section{DAFTAR PUSTAKA}

Adri, 2008. factor- factor yang mempengaruhi cakupan program pemeriksaan kehamilan (K1 dan K4) di Puskesmas Runding subulussalam provinsi NAD. Tesis. Sekolah pasca sarjana
Universitas Sumatera Utara.(Online) diakses tanggal 26 Juni 2017.

Ain Fathmi. 2012.Hubungan Indeks Massa Tubuh dengan KadarGula Darah Pada Penderita Diabetes Melitus Tipe 2 di Rumah Sakit Umum Daerah Karanganyar.

American Diabetes Association, 2015. Standards of Medical Care in Diabetes -2008. Diakses pada tanggal 5 Agustus 2017 dari http://www.ndei.org/v2/website/go /articles/Standards_of_medical_car e_in diabetes_2008_/

American Heart Association. (2012). Hearth Disease and Stroke Statistik. Diakses pada tanggal 5 Agustus 2017 dari http://ahajournal.org.com.

Andersen, Ronald \& John F. Newman, 2005, 'Societal and Individual Determinants of Medical Care Utilization in the United States'. The Milbank Quarterly

Ansari, R., Khosvari, A. \& Bahonar, A., 2012. Risk factors of atherosclerosis in male smokers, passive smokers, and hypertensive nonsmokers in central Iran. ARYA atherosclerosis, 8(2), pp.905. Available at: http://www.pubmedcentral.nih.gov /articlerender.fcgi?artid=3463995 \&tool=p mcentrez\&rendertype $=$ abstract [Akses tanggal 5 April 2017].

Arikunto, S. 2010. Prosedur penelitian : Suatu Pendekatan Praktik. (Edisi Revisi). Jakarta : Rineka Cipta

Barnes, Darryl E. 2004. Program Olahraga: Diabetes Mellitus.Alih bahasa: Aburiyati. Yogyakarta: PT. Citra Aji Parama.

Bhadoria, A., Kasar, P. \& Toppo, N., 2014. Prevalence of hypertension and associated cardiovascular risk factors in Central India. Journal of family \& community medicine, 
21(1), pp.29-38. Available at: http://www.pubmedcentral.nih.gov /articlerender.fcgi .artid=3966094 \&tool $=\mathrm{p}$ mcentrez\&rendertype $=$ abstract [Akses tanggal 5 April 2017].

Bhadoria, A., Kasar, P. \& Toppo, N., 2014. Prevalence of hypertension and associated cardiovascular risk factors in Central India. Journal of family \& community medicine, 21(1), pp.29-38. Available at: http://www.pubmedcentral.nih.gov /articlerender.fcgi?artid=3966094 \&tool $=\mathrm{p}$

mcentrez\&rendertype $=$ abstract

[Akses tanggal 5 April 2017].

BPJS Kesehatan. 2014.Panduan Praktis

Prolanis (Program Pengelolaan Penyakit Kronis). Jakarta: BPJS Kesehatan.

Bustan M.N. 2007. Epidemiologi: Penyakit Tidak Menular; Rineka Cipta, Jakarta.

Canadian Diabetes Association, 2008. Guidelines for the Nutritional Management of Diabetes Mellitus in the New Millennium. Diakses pada tanggal 5 Agustus 2017 dari http://www.diabetes.ca/files/nutriti onal_guide_eng.pdf.

Corwin, E. 2005. Buku Saku Patofisiologi. Jakarta

Darmono. 2009. Pengaruh Pola Hidup Klien Diabetes Untuk Mencegah Komplikasi Kerusakan OrganOrgan Tubuh. Diakses tanggal 26 Agustus 2017. Available at http://edrints.undip.ac. id/371/1/Darmono.

Depdiknas. 2002. Kamus Besar Bahasa Indonesia. Edisi 3. Jakarta: Balai Pustaka.

Ehsa. (2010). Diabetes Melitus. Diakses pada tanggal 5 Agustus 2017 http://ehsablog.com/diabetesmelitus-dm.html
Fitriyanti, 2005 : Motivasi Penderita Diabetes Melitus Tipe II Dalam Mengikuti Kegiatan Olah raga Pada anggota PERSADIA Cabang Pekalongan.

Gerungan, W.A. 2004.PsikologiSosial, PT. Refika Aditama, IKAPI, Bandung

Goldenberg, R., Mikalachki, A., Prebtani., Punthakee, Z. 2013. Reducing the Risk of Developing Diabetes. Canadian Diabetes Association Clinical Practice Guidelines Expert Committee, Canadian Journal of Diabetes Volume 13

Guyton. 2007. Fisiologi Manusia dan Mekanisme Penyakit. EGC. Jakarta.

Hamano, T., Kimura, Y. \& Takeda, 2012. Effect of environmental and lifestyle factors on hypertension: Shimane COHRE study. PloS one, 7(11), p.e49122. Available at: http://www.pubmedcentral.nih.gov /articlerender.fcgi?artid=3494668 \& tool $=\mathrm{p}$ mcentrez\&rendertype $=$ abstract [Akses tanggal 5 April 2017].

Henderina. 2010. DM Pada Lansia, Kasus Besar Interna. Diakses pada tanggal 5 Agustus 2017 dari http//www.scribd.com/doc/724588 47/dm-pada-lansia

IDF(International Diabetes Federation) 2005. Diabetes : A Major Risk Factor. Diakses pada tanggal 5 Agustus 2017 dari http://www.idf.com.

IDF(International Diabetes Federation). 2003. Diabetes and Cardiovaskuler Disease. Diakses pada tanggal 5 Agustus 2017 dari http://www.idf.com.

Inzucchi, E., 2003. The Diabetes Melitus Manual. Singapura

Jafar, Nurhaedar. 2010. Hipertensi. Makassar : fakultas kesehatan masyarakat, 2010. 
Muliyati Hepti, 2011. Hubungan Pola Konsumsi Natrium dan Kalium serta Aktivitas Fisik dengan Kejadian Hipertensi pada pasien Rawat jalan di RSUP DR. Wahidin Sudirohusodo Makasar. http://journal.unhas.ac.id [Akses tanggal 5 April 2017].

Nasution (2013) dengan judul Pengaruh Pengetahuan, Sikap, Dukungan Keluarga dan Kader terhadap Pemanfaatan Posyandu Lanjut Usia di Wilayah Kerja Puskesmas Bandar Dolok Kecamatan Pagar Merbau Kabupaten Deli Serdang. Diakses pada tanggal 5 Agustus 2017 dari http://repository.usu.ac.id/bitstrea $\mathrm{m} /$ handle/123456789/35579/Cover .pdf? sequence $=7$.

Nguyen, T. \& Lau, D.C.W., 2012. The obesity epidemic and its impact on hypertension. The Canadian journal of cardiology, 28(3), pp.326-33. Available at: http://www.ncbi.nlm.nih.gov/pubm ed/22595448 [Akses tanggal 5 April 2017].

Niven, N., 2008. Psikologi Kesehatan Pengantar Untuk Perawat Dan Profesional. Penerbit EGC Jakarta.

Notoatmodjo, S. (2010). Metodologi penelitian kesehatan. Jakarta : PT. Rineka Cipta

Nursalam. 2009. Konsep dan Penerapan Metodologi Penelitian Ilmu Keperawatan : Pedoman Skipsi, Tesis, dan Instrumen Penelitian Keperawatan.Jakarta : Salemba Medika

Pandelaki, K. (2009). Retinopati diabetik. In A. W. Sudoyo, B. setiyohadi, I. Alwi, M. S. K \& S. Setiati (Eds.),Buku ajar ilmu penyakit dalam jilid III edisi $v$. Jakarta: InternaPublishing.

PERKENI 2011. Konsensus Pengelolaan dan pencegahan
Diabetes Mellitus tipe 2 tipe 2 di Indonesia. Jakarta.PB PERKENI

PERKENI, 2011. Konsensus Pengelolaan dan Pencegahan Diabetes Melitus Tipe 2 di Indonesia, Diakses pada tanggal 5 Agustus 2017 dari www.perkeni.org

PERKENI. 2006. Konsensus Pengelolaan dan Pencegahan Diabetes Mellitus Tipe 2 di Indonesia. Jakarta : PB. PERKENI Price, S. A. 2005. Patofisiologi : Konsep Klinis Proses-Proses Penyakit (Edisi 6.Vol 2). Jakarta:EGC

Sahlasaida. 2015. Penyakit Diabetes Melitus, Penyebab dan Gejalanya. Diakses pada tanggal 5 Agustus 2017 dari http://tipkesehatan.com/2015/10/pe nyakit-diabetes-melitus-penyebabdan-gejalanya/

Satrianegara, M. Fais. 2014. Organisasi dan Manajemen Pelayanan Kesehatan. Jakarta : Salemba Medika.

Sitompul, R., 2011. Retinopati Diabetik. Juornal Indonesia Medical Association. Vol 61. 2011.

Smeltzer, S.Bare,B. 2002. Buku Ajar Keperawatan Medikal Bedah. Brunner \& Suddarth. Ed.8. Vol 2. Jakarta: EGC

Soekanto Soerjono. 2001. Sosiologi: Suatu Pengantar. Jakarta: Raja Grafindo Persada.

Soekanto, Soerjono. Sosiologi Suatu Pengantar. Jakarta: Rajawali Pers, 2012.

Subari, N.D. 2008. Hubungan Antara Dukungan Keluarga Dengan Kepatuhan Penderita Diabetes Mellitus Dalam Mengikuti Senam di Klub Senam Diabetes Mellitus RS dr. Oen Solo Baru. Skripsi Fakultas Ilmu Kesehatan Universitas Muhammadiyah Surakarta 
Subekti, I. (2009). Neuropati Diabetik. In A. W. Sudoyo, B. Setiyohadi, I. Alwi, M. S. K \& S. Setiati (Eds), Buku ajar ilmu penyakit dalam jilid III edisi v. Jakarta: InternaPublishing.

Subekti, I., 2009. Organisasi Diabetes di Indonesia. Dalam : Soegondo, S., Soewondo,P., Subekti, I., Penatalaksanaan Diabetes Melitus Terpadu. Fakultas Kedokteran Universitas Indonesia, Jakarta : 231.

Sudjana, Nana. 2005. Penilaian Hasil Proses Belajar Mengajar. Bandung: Remaja Rosdakarya

Sugiarto, BW \& Suprihatin. 2012. Kepatuhan Kontrol dengan Tingkat Kadar Gula Darah Pasien Diabetes Mellitus di Rumah Sakit Bapitis Kediri. Jurnal STIKES.

Sugondo, 2007. Obesitas. Dalam: Sudoyo AW, Setiyohadi B, Alwi I, Simadibrata KM, Setiati S, editor (penyunting). Buku Ajar Ilmu Penyakit Dalam Jilid III. Edisi ke - 4. Jakarta : Departemen Ilmu Penyakit Dalam FKUI; 2007.

Suiraoka, 2012. Penyakit Degeneratif, Mengenal, Mencegah dan Mengurangi Faktor Risiko 9 Penyakit Degeneratif, Yogyakarta: Nuha Medika.

Sunaryo. (2006). Psikologi untuk Keperawatan. EGC: Buku Kedokteran

Sundari, S., Aulani'am, A. \& Wahono, S., 2013. Faktor Risiko Non Genetik dan Polimorfisme Promoter Regionm Gen CYP11B2Varian T(-344)C Aldosterone Synthasepada Pasien Hipertensi Esensial di Wilayah Pantai dan Pegunungan. Jurnal Kedokteran Brawijaya, 27(3), pp.pp.169-177. Available at: http://jkb.ub.ac.id/index.php/jkb/ar ticle/view/345 [Akses tanggal 5 April 2017].
Suryabrata, Sunardi. 2002. Psikologi Pendiidkan. Jakarta: PT. Raja Grafindo Persada.

Tjokroprawiro, A. (2006). Hidup Sehat dan Bahagia Bersama Diabetes Melitus. ISBN 979-655-140-1. Jakarta: Gramedia.

Umiyati, S., 2011. Pengaruh kebiasaan merokok terhadap kejadian hipertensi pada laki-laki usia di atas 40 tahun di Dusun Kampung Baru Desa Sentul Kecamatan Purwodadi Kabupaten Pasuruan tahun 2011. http://fkm.unair.ac.id/detail [Akses tanggal 5 April 2017].

Usman, Uzer. 2009. Menjadi Guru Profesional . Bandung: PT. Remaja Rosdakarya.

WHO. (2012). World Health Statistic. Diakses pada tanggal 5 Agustus 2017 dari http://search.who.int/search?q=pre valence + of + heart+failure \&spell $=1$ $\&$ ie $=$ utf $8 \&$ site $=$ who $\&$ clien 
